\title{
BIM OPPORTUNITIES AND CHALLENGES IN CONSTRUCTION STUDY PROGRAMS AT LATVIA UNIVERSITY OF LIFE SCIENCES AND TECHNOLOGIES
}

\author{
Sandra Gusta, Silvija Strausa, Janis Freimanis \\ Latvia University of Life Sciences and Technologies, Latvia \\ sandra.gusta@1lu.lv, silvija.strausa@1lu.lv, janis_freimanis@inbox.lv
}

\begin{abstract}
The construction industry is considered to be a conservative industry, and, looking back into the history of the industry, modern digital tools have only started to play a role in a relatively recent period, but have already managed to significantly change the design, construction and management processes, their specifics, as well as the necessary competencies of the parties involved. This is mainly due to the third technological revolution, especially during the last two decades, when the extremely rapid development and availability of solutions of information and communication technologies has taken place. At present, in the private sector, companies operating in project supply chains (material manufacturers and suppliers, designers, builders) in the private sector can use the benefits of technology to increase their competitiveness and profitability. However, in Latvia, due to the public sector's order quantity and the fact that the demands on the project execution process are conservative in these orders, companies have so far been passive in introducing innovations. Companies in the supply chain of construction projects are not the only ones who can benefit from the use of new technologies. Among the winners are project contractors in both the private and public sectors. Therefore, it is necessary in construction study programs of universities to integrate BIM training by improving the content of the study program in accordance with the new demand. The research task is to find out the necessary knowledge, skills and competences of the graduates of university for working in so complicate managing process. It is also important to find out how to improve the study program according to the new and complex view from the first steps of construction to the operation of the building.
\end{abstract}

Keywords: BIM, Building Information Modelling, BIM integration.

\section{Introduction}

\section{A Brief History}

Construction industry in the whole world is facing a digitalization which has taken place since the Computer-Aided Design (CAD) was adopted by architects, design engineers and other construction industry professionals during the late 20th century [1].

Having started evolving in 1940s together with the development of computers, Computer-Aided Design subsequently evolved to commercial systems by the end of 1960s. At that point it started to become widely recognized that these systems can reduce operating costs for engineering companies by creating automated processes to generate standardized drawings. It replaced a lot of repetitive work and therefore increased productivity. Throughout the 1970s, the CAD industry grew from virtually zero to a billion US dollar worth global hardware and software business [2].

However, whether it is preparation of drawings by hand or in CAD environment, due to the Human Error interdisciplinary collisions are inevitable when working in 2D environment.

As it has been discovered, Human Error is a phenomenon possessed by any person and it can be controlled to a certain extent by using various process quality improvement techniques as well as technological means, but cannot be eliminated completely [3]. That is a potential advantage, where concept of 3D modelling as a technological mean for reduction of Human Error starts, but does not end.

It is considered that it was 1975 when the first publication defining BIM concept was released [4]. It was "The Use of Computers Instead of Drawings in Building Design" written by Charles M. Eastman and the concept defined in the publication called Building Description System (BDS). It included ideas of parametric design, deriving 2D drawings from a model, a "single integrated database for visual and quantitative analyses" and it was suggested that "contractors of large projects may find this representation advantageous for scheduling and material ordering" [5].

Later on, at 1982 the 3D modelling using personal computers was introduced by Hungarian physician Gabor Boyar through software Radar $\mathrm{CH}$ which was later renamed as ArchiCAD [6]. Subsequently other software developers created similar concept products and since then various BIM solutions have been developing all over the world and still are. 
After the emergence of the World Wide Web in 1990s the use of web-based information management systems became common. Together with the development of cloud-based solutions it provided all the prerequisites for integration with BIM models and that led to integrated building information solutions which are today known as Common Data Environments [4].

\section{BIM Terms and Definitions}

Acronym BIM is generally understood as Building Information Modelling, but there are also versions as Building Information Model and Building Information Management.

Building Information Model refers to a digital representation of physical and functional characteristics of a facility. As such it serves as a shared knowledge resource for information about a facility, forming a reliable basis for decisions during its life cycle from inception onwards [7].

Building Information Management is a wider term and it refers to the organization and control of the business process by utilizing the information in the digital prototype to effect the sharing of information over the entire lifecycle of an asset. The benefits include centralized and visual communication, early exploration of options, sustainability, efficient design, integration of disciplines, site control, as built documentation, etc.- effectively developing an asset lifecycle process and model from conception to final retirement [7]. In this context information is understood as building information models as well as any other forms of building information [8].

In this article BIM generally stands for Building Information Modelling. An aspect of Building Information Management in the context of Building Information Integration using Common Data Environment also will be looked at.

Building Information Modelling has various definitions. Here are some of those.

1. In accordance with the stated uses, an integrated process of construction design, engineering, construction and management, technologies and set of rules that allow multiple parties to jointly design, construct, and manage a building in a digital environment [8].

2. A business process for generating and leveraging building data to design, construct and operate the building during its lifecycle. BIM allows all stakeholders to have access to the same information at the same time through interoperability between technology platforms [7].

3. A process of designing, constructing or operating a building or infrastructure asset using electronic object-oriented information $[9 ; 10]$.

Other definitions interpret BIM as a technology, a process or an information resource or integrated set of these meanings. None of those and above-mentioned definitions is in contradiction with each other, because BIM can mean something else for different project stakeholders and participants of project supply chains.

\section{BIM Dimensions beyond 3D}

As the information technologies evolve, further integration possibilities of various project information types with BIM 3D models are being discovered and proved to be effective. As in some cases it means additional new type of information integrated with model, it has led to using word "dimensions" to describe the additional information or integrated state of a model. Here are listed the most widely known concepts of BIM dimensions:

BIM 4D - a construction schedule integration with BIM model by linking time component to particular or all the assets included in model. Time component can refer to information about delivery, assembly, demolition, temporary uses of an asset etc.

BIM 5D - a cost link age to a BIM model to enable project management team to visualize, analyze and predict easier the dynamics of costs for a project progression.

BIM 6D and 7D concepts are not unanimous so far. They may refer to:

- software capabilities of energy analyses and/or sustainability analyses for buildings designed in BIM environment;

- model integration with additional technical information for facility management purposes after the project design and construction is finished;

- materials and objects tracking by using Radio Frequency Identification (RFID) [11; 12]. 
In different information sources different combination of these concepts is used for 6D and 7D BIM. Also, these concepts do not mean additional type of information integrated within a model, but rather extended uses of a model as well as software capabilities, therefore it is disputable whether term "dimension" is applicable.

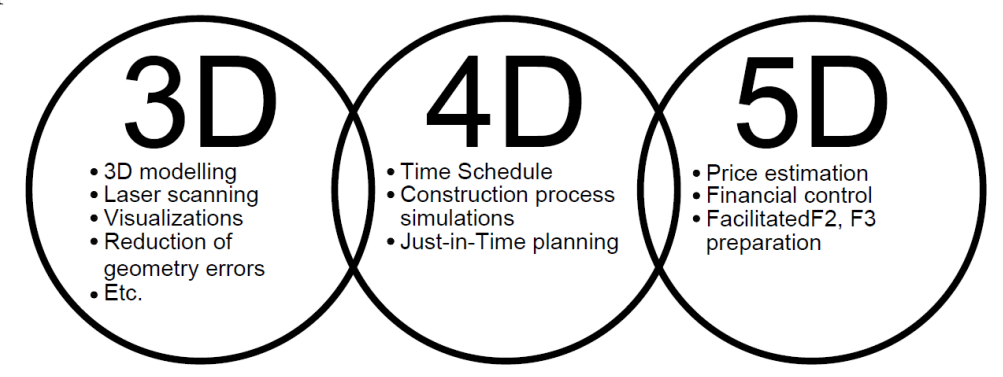

Fig. 1. Basic BIM Dimensions [13]

\section{Building Information Integration}

A concept of full building information integration is well defined in PAS 1192-2:2013 "Specification for Information Management for the Capital/Delivery Phase of Construction Projects using Building Information Modelling" and it is referred to as Common Data Environment (CDE).

$\mathrm{CDE}$ - a single source of information for any given project, used to collect, manage and disseminate all relevant approved project documents for multi-disciplinary teams in a managed process. A CDE may use a project server, an extranet, a file-based retrieval system or other suitable toolset [9].

Use of CDE can facilitate collaboration through improved information exchange technology, reduction of communication channels between stakeholders and reduction of risks related to involved parties using different or outdated information revisions [9].
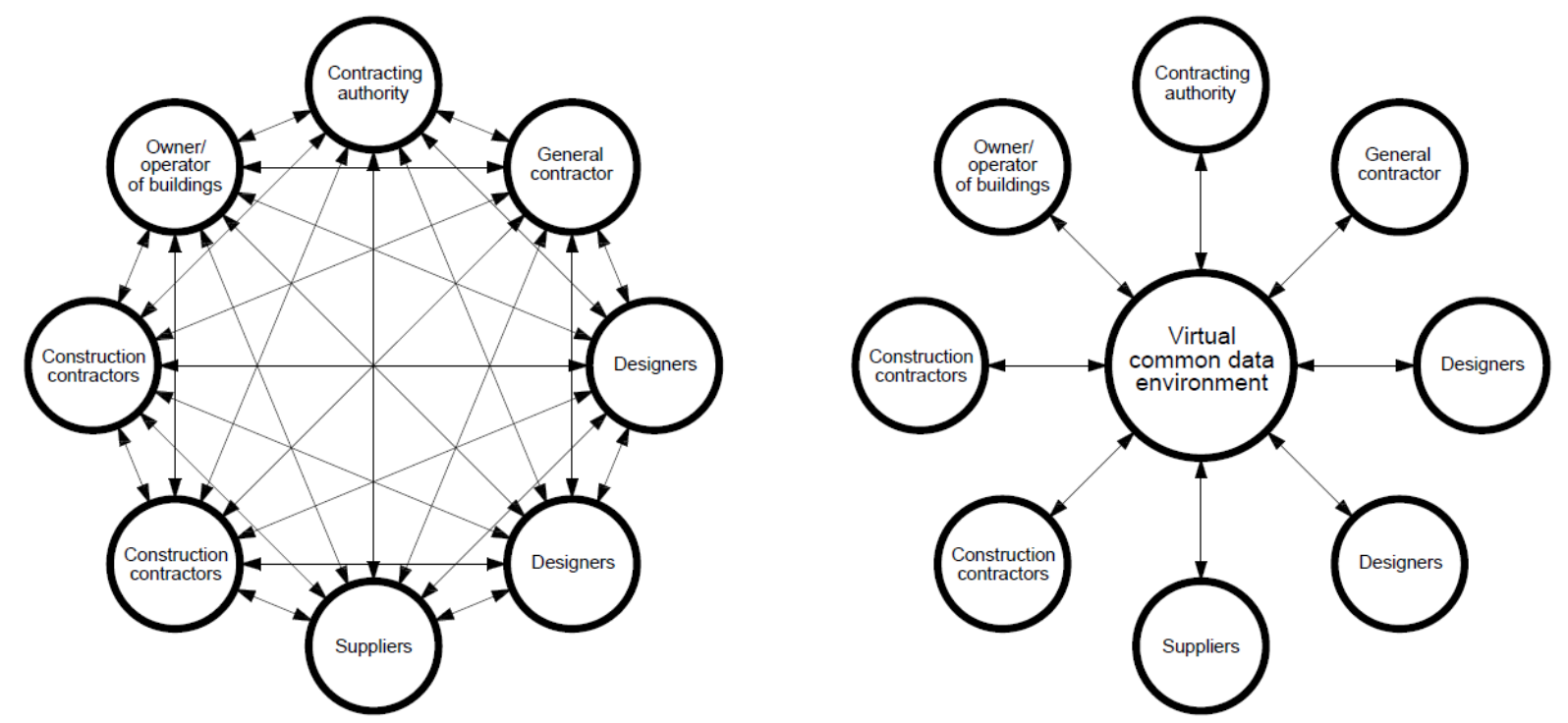

Fig. 2. Classical collaboration model and Common Data Environment - based model [13]

\section{Materials and Methods}

Understanding of BIM theory and direction of global BIM development tendencies was deepened through literature reviews. There is a significant lack of Latvian literature regarding the subject. Considering that BIM development leadership can be observed at United Kingdom and United States of America through respective standards development [8,9], main focus is aimed at English literature additionally to international scientific proceedings.

To develop a comprehensive understanding of BIM maturity and development tendencies in Latvia, semi-structured interviews with experts were conducted as well as literature reviews. 
Lately there have become available Bachelor's thesis on BIM integration within similar study program in Riga Technical University [14] and master's thesis on BIM implementation within Latvian construction company [15] as well as foreign literature regarding this topic [16]. The mentioned scientific material has been used as a guideline on what already has been researched regarding the topic and to identify further steps needed for research.

A previous investigation on sustainability of Latvian construction industry has been taken into consideration $[17 ; 18]$.

Based on information acquired, SWOT analysis has been done for BIM integration within Civil Engineering study program at the Latvia University of Life Sciences and Technologies (see Table 1).

\section{Results and Discussion}

Regarding construction in Latvia, the latest data compiled by the Central Statistical Bureau (CSB) show that, compared to the corresponding period of 2016, in the 3rd quarter of 2017 construction output increased by $25 \%$ (according to calendar adjusted data at constant prices). Construction output at current prices amounted to 580.8 million euros. Compared to the 3rd quarter of the previous year, significant construction output increase was recorded in construction of civil engineering works (of $39.6 \%$ and comprising $50.9 \%$ of the total construction output) and construction of non-residential buildings (of $25.2 \%$ and comprising $38.8 \%$ of the total construction), while construction of residential buildings fell by $18 \%$. Within the construction of civil engineering works, construction of harbours, waterways, dams and other waterworks grew twice; notable increase was observed also in construction of long-distance pipelines, communication and electricity lines (of $67.7 \%$ ) and construction of highways, streets and roads, airfield runways, and railways (of $28.2 \%$ ). Within the construction of non-residential buildings, significant rise was registered in construction of wholesale and retail trade buildings (of $90 \%$ ), construction of office buildings $(60.6 \%$ ), construction of school, university and research buildings $(44.1 \%)$, as well as construction of industrial buildings and warehouses $(23.6 \%)$.

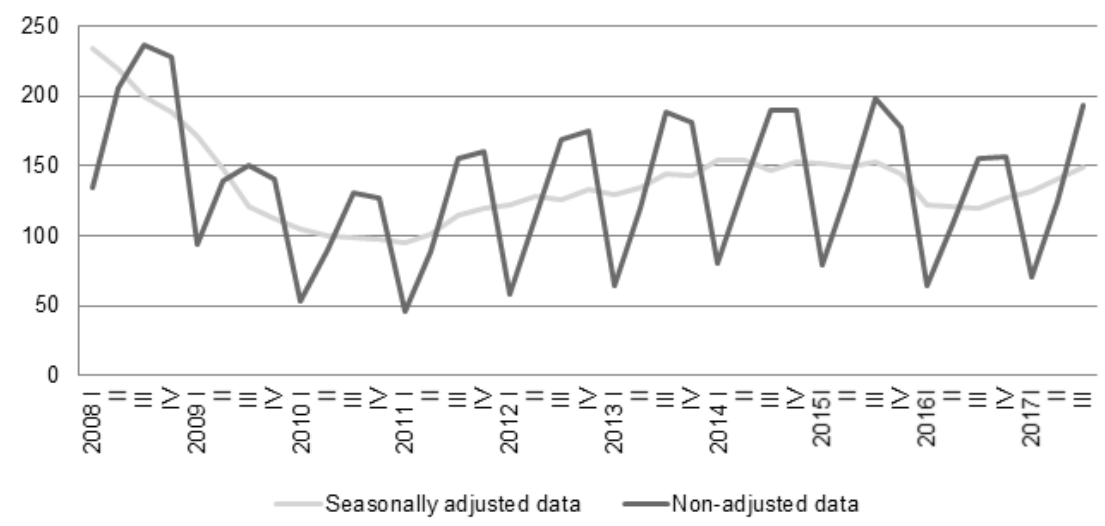

Fig. 3 Index of production in construction $(2010=100)[19]$

In the $3^{\text {rd }}$ quarter of 2017,901 building permits were granted for the construction, capital repairs, reconstruction and restoration of single dwelling buildings with the total floor space of 179.7 thousand $\mathrm{m}^{2}$, of which 699 permits were issued for construction of new buildings with the intended floor space of 135.9 thousand $\mathrm{m}^{2}$ (297 permits more than in the $3^{\text {rd }}$ quarter of 2016). In its turn, 81 building permits ( 2 times more than in the corresponding quarter of the previous year) were granted for construction of industrial buildings and warehouses with the total intended floor space of 169 thousand $\mathrm{m}^{2}$, of which 48 building permits were issued for new construction with the intended floor space of 72.9 thousand $\mathrm{m}^{2}$.

Data shows that growth is expected in the construction sector, which is why it is particularly important to improve the efficiency of the construction industry [20]. One of the ways is the introduction of BIM in the construction industry. 


\section{Pros and Cons of BIM adoption for the organizations operating in the construction sector}

The following advantages can be outlined as the main ones:

1. Improved project planning and design processes utilizing previously described BIM applications;

2. Decreased time for change order implementation, less redundant work and errors in project documentation;

3. Less problems in the construction field due to necessary deeper problem analysis for modelling elements instead of drawing development using lines;

4. Materials economy due to higher precision of bills of quantities derived directly from model;

5. Improved communication between involved parties and other stakeholders due to availability of visual materials without need for extra work, therefore improving perception of problems highlighted;

6. Support for manufacturing processes and improvements of industrialization level by using modelling that can be integrated with production processes.

The following disadvantages can be outlined as the main ones:

1. Contractual obligations and definition for development of BIM content. Though BIM is being considered a project cost-reducing process, its implementation and execution itself is not costfree. It includes significant amount of training and purchase of appropriate and powerful enough hardware as well as software licenses. At the same time different understanding of Levels of model Development (Level of Detail + Level of Information) for BIM content and other Employer's Information Requirements (EIR) between contractors leads to conflict. Therefore, it is necessary to create a well detailed BIM Execution Plan before any design works take place.

2. Lack of compatibility between project parties' authoring tools. There are many different BIM content development and management tools on the market. This fragmentation leads to an increased possibility of compatibility issues that impair collaboration of project parties. This problem will persist as long as strict strategy and standards will not be developed and implemented regarding model content and representation.

3. Inability of state institutions to adapt to the new way of work. Obsolete, unreasonable requirements based on old approaches are set by state institutions, which leads to extra manual redundant work for involved parties. For example, color passport for external surfaces is required to be created the old way as a list in a table, but working with BIM tools it is faster and easier to show colors and their codes next to the particular surface in the drawing. Due to this requirement content has to be created manually which needs to be controlled manually every time changes are implemented to a project which therefore leads to higher probability of errors.

4. Cost of software which depends on providers that have acquired a position close to monopoly in the market.

5. Lack of knowledge and experienced specialists. As learning BIM processes can be complicated, the necessary knowledge and working culture is developed within a relatively long period of working with BIM tools. The significant lack of specialists is contributed also by higher educational institutions falling behind the industry tendencies.

6. Progressive complexity of IT systems. IT systems used in the market are becoming more sophisticated and are being developed by different providers with problem situations that don't have off-the-shelf explanations and solutions.

Analysis and evaluation of the existing study program was carried out within the framework of the research. Goals of the study programs and acquirable results of particular study courses are identified: knowledge, competencies and skills. Existing technically - economical resources are identified. A SWOT analysis for BIM integration within the study program has been carried out and is shown in Table 1.

After familiarisation with the international and especially Scandinavian experience on BIM implementation within construction and assets operations processes, authors have concluded that progression towards three-dimensional building model should be integrated within the study program. Intercompatible between different disciplines models production and automated calculations-based design should be developed and the model ultimately should consist any information needed for construction. 
SWOT analysis for BIM integration within Civil Engineering study program

(Created by authors)

\begin{tabular}{|c|c|l|}
\hline & No. & Strengths \\
\hline & 1 & $\begin{array}{l}\text { Faculty and the number of students are relatively small, therefore a better coordinated, } \\
\text { cheaper and more effective implementation of BIM integration is possible }\end{array}$ \\
\hline 2 & Faculty with all the personnel is located at the same place \\
\hline 3 & Hardware is already bought and set up \\
\hline 1 & $\begin{array}{l}\text { Weaknesses } \\
\text { experience on implementation of such projects }\end{array}$ \\
\hline 2. & Lack of teaching staff experienced with BIM systems \\
\hline 1 & $\begin{array}{l}\text { Budget restrictions } \\
\text { Opportunities }\end{array}$ \\
\hline 2 & $\begin{array}{l}\text { Strategic goals on the state level to implement sustainable construction process and } \\
\text { expected potential forward coming and support from the private sector }\end{array}$ \\
\hline 3 & NGO and public sector's initiatives for BIM development \\
\hline 4 & \begin{tabular}{l} 
BIIG initiative \\
\hline 5
\end{tabular} & $\begin{array}{l}\text { Potential for knowledge sharing with Riga Technical University which has started BIM } \\
\text { integration within similar study program }\end{array}$ \\
\hline 6 & Cooperation with foreign universities that have already implemented the integration \\
\hline & Threats \\
\hline 1 & Relatively low level of BIM maturity in Latvia \\
\hline 2 & $\begin{array}{l}\text { Lack of standards adapted for local market and legislation, lack of common } \\
\text { understanding on BIM competencies needed }\end{array}$ \\
\hline 3 & $\begin{array}{l}\text { Highly fragmented software use on the market combined with OpenBIM solutions still } \\
\text { in development complicates selection of most appropriate software to teach and } \\
\text { universal application of learned skills }\end{array}$ \\
\hline
\end{tabular}

The goal of the study program is to prepare civil engineers able to work within teams as qualified structural engineers, site managers and construction process supervisors. Diploma project should contain architectural drawings of a building derived from 3D model, MEP networks should be coordinated within the model. Structural design section should be included with added automated design results using BIM software. A valid shedule of construction works, selection of technologies and machinery, quality control, bills of quantities and cost estimates should be developed.

Vertically progressive study plan through semesters is divided in study courses and final engineering work and involves teamwork, which ultimately provides education for structural engineers, site managers and construction process supervisors. See Table 2.

The closest stages of BIM integration within the study program:

- Providing computer classrooms with all the necessary software (Vico / Autodesk Navisworks)

- Dvelopment of common understanding on BIM principles

- Establishing 3D model-based design process

- Development and implementation of sequential design process through study semesters and milestones for developed design at the end of each semester to assess the achieved level of model development.

The block of study courses consisting of Descriptive Geometry, Construction Graphics, Chemistry, Building Materials, Architecture, Building Physics and Heat Processes provides 3D model development for various types of buildings (residential, public, production, agricultural), dimensioning of building envelope structures, detailed architectural drawings development and material specifications development. 
Breakdown of Civil Engineering Study Program by Semesters and Study Courses

Table 2

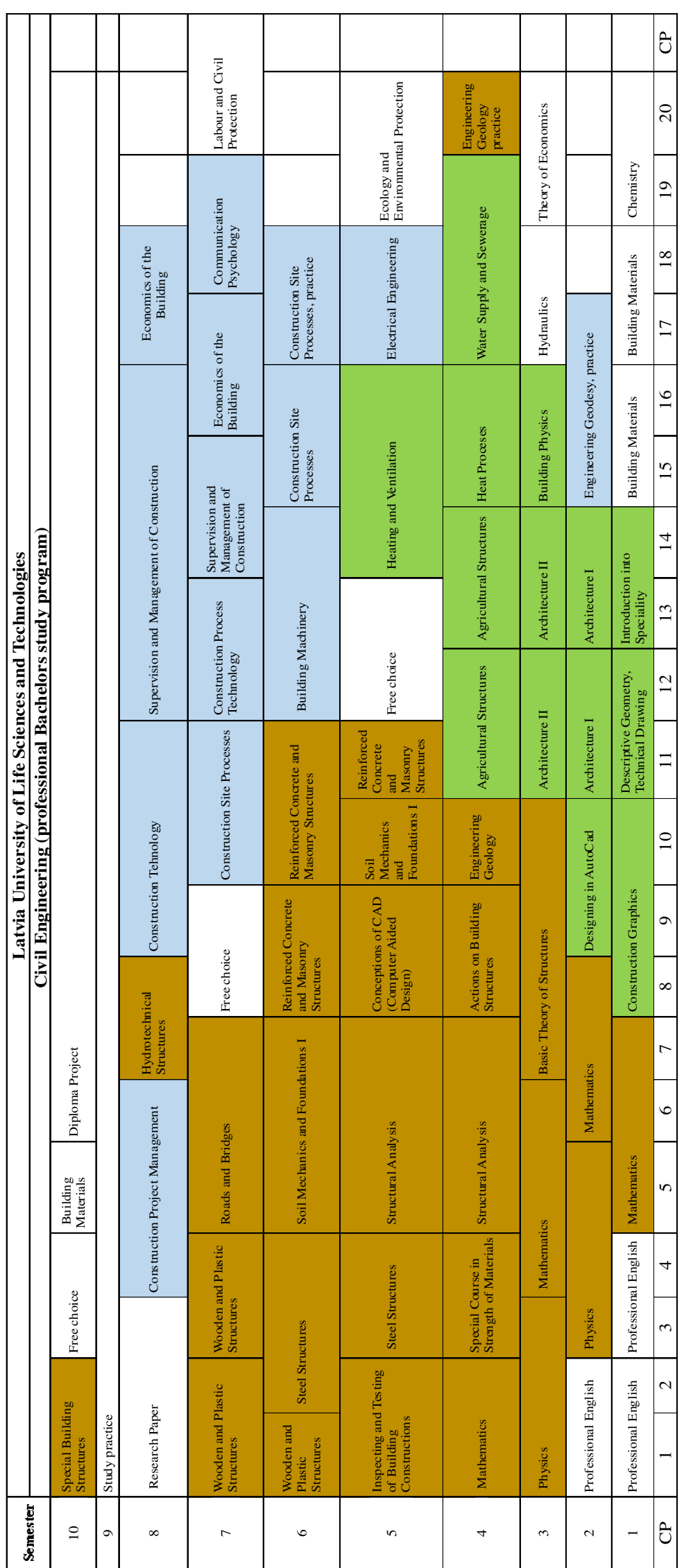


The study courses Hydraulics, Water Supply and Sewerage, Heating and Ventilation provide insight on design process of MEP building engineering networks.

The block of study courses consisting of Mathematics, Physics, Basics of Building Theory, Special Course in Strength of Materials, Actions on Structures, Basics of CAD, Building Mechanics, Inspecting and Testing of Building Constructions, Soil Mechanics and Foundations, Roads and Bridges, Reinforced Concrete and Masonry Constructions, Steel Structures, Wooden and Plastic Structures provides students with skills for structural design and development of 3D model-based detailed shop drawings and specifications.

The block of study courses consisting of Construction Processes, Construction Process Technology, Construction Machinery, Supervision and Management of Construction, Construction Economics, Engineering Geodesy, Project Management provides knowledge about sequence and technology of construction works, optimal selection of construction machinery, time rates of construction works and price estimation.

It is envisaged that 3D models created in any study courses will be compatible with models created in any other courses therefore enabling collaborative study process.

\section{Conclusions}

1. The study program is well developed, with gradual and sequential learning of knowledge, competencies and skills;

2. The necessary software for 3D structural design has been provided and in structural design study courses the software applications are being learned to the necessary level;

3. 3D design has to be introduced to the architectural study courses using Autodesk Revit for general architectural modelling and Tekla Structures for detailed design;

4. Construction Technology has to be taught involving use of VICO or Autodesk Navisworks software;

5. BIM coordination study course has to be introduced;

6. Training of instructors has to be done.

\section{References}

[1] Cszmoch I., Pekala A. "Traditional Design versus BIM Based Design" Proceedings of International Conference "Theoretical Foundation of Civil Engineering", June 25-29, 2014, Wroclaw, Poland, pp. 210-215.

[2] Weisberg D. E. The Engineering Design Revolution. The People, Companies and Computer Systems That Changed Forever the Practice of Engineering. Englewood, 2008, 402 p.

[3] Wenwen S. Fuchuan J. Quiang Z. Jingjing C. "Analysis and Control of Human Error" Proceedings of International Conference "First International Symposium on Mine Safety Science and Engineering" September 6-8, 2011, Kunming, China, pp. 2126-2132.

[4] Bartley T. BIM for Civil and Structural Engineers. London: BSI, 2017. 15 p.

[5] Eastman C. M. The use of computers instead of drawings in building design. Pittsburgh: Carnegie Mellon University, 1975. 6 p.

[6] Goubau T. A History of BIM. Brussels: Aproplan, 2016. [online] [04.03.2018]. Available at: https://www.aproplan.com/blog/construction-collaboration/a-history-of-bim.

[7] National BIM Standard - United States Version 3 Washington: National Institute of Building Sciences, 2018, $2538 \mathrm{p}$.

[8] LVS 1052:2018 "Building Information Modelling (BIM) terminology"

[9] PAS 1192-2:2013 "Specification for information management for the capital/delivery phase of construction projects using building information modelling"

[10] PAS 1192-3:2014 "Specification for information management for the operational phase of assets using building information modelling"

[11] McPartland R. BIM dimensions - 3D, 4D, 5D, 6D BIM explained. Newcastle upon Tyne: theNBS, 2017. [online] [05.03.2018]. Available at: https://www.thenbs.com/knowledge/bimdimensions-3d-4d-5d-6d-bim-explained. 
[12] Elsafadi H. BIM 3D to 7D implementation. London: London Metropolitan University, 2016. [online] [05.03.2018]. Available at: https://www.linkedin.com/pulse/bim-3d-7d-implementationhani-elsafadi/.

[13] Freimanis. J. "Aktuālais BIM”. Journal "Būvinženieris". Rīga: LBS, 2018.

[14] Ronis K. R. BIM procesu integrācija studiju programmā "Būvniecība". Bachelor's thesis. Jelgava: LLU, 2018. 226p.

[15] Baltgalve M. Būves informācijas modelēšanas (BIM) ieviešana būvniecības uzṇēmumā Latvijā. Master's thesis. Riga: RTU, 2018. 269 p.

[16] Fridrich J., Kubečka K. BIM - The Process of Modern Civil Engineering in Higher Education. Proceedings of International Conference "World Conference on Learning, Teaching and Educational Leadership", October 27-29, 2013, Barcelona, Spain, pp. 763-767.

[17] Gusta S. Building as long-term environmental development and preservation condition. Proceedings of international scientific conference "Civil Engineering '11", May 12-13, 2011, Jelgava, Latvia, pp. 256.-262.

[18] Gusta S. Sustainable construction in Latvia - opportunities and challenges. Proceedings of international scientific conference "Engineering for rural development", May 25-27, 2016, Jelgava, Latvia, pp. 1291-1299.

[19] Central Statistical Bureau of Latvia. [online] [20.02.2017.] Available at: http://www.csb.gov.lv/statistikas-temas/buvnieciba-galvenie-raditaji-30294.html

[20] 2017.gadā būvniecības apjomi nozīmīgi pieauga. [online] [20.02.2017. Available at: https://www.em.gov.lv/lv/nozares_politika/buvnieciba/statistika_petijumi/

[21] Latvijas Būvniecības nozares attīstîbas stratēgija 2017. - 2024. gadam (Development Strategy for Latvian Construction Industry for years 2017-2024). Rīga: Latvijas Būvniecības padome (Latvian Construction Council), 2017, 14 p. 